\title{
SPERGILLI ON BUILDING PARTITIONS INFESTED WITH MOULDS IN RESIDENTIAL HOUSING AND PUBLIC UTILITY PREMISES
}

\author{
Marlena PIONTEK ${ }^{1}$, Katarzyna ŁUSZCZYŃSKA, Hanna LECHÓW \\ University of Zielona Gora, Zielona Góra, Poland
}

\begin{abstract}
Aspergilli constitute a serious risk to the health of the inhabitants of infested rooms. Mycological analysis conducted in buildings infected with moulds in the area of the Lubuskie province (Poland) demonstrated the presence of 9 species of Aspergillus moulds: A. carbonarius A. clavatus, A. flavus, A. fumigatus, A. niger, A. ochraceus, A.terreus, A ustus and A. versicolor. The highest frequency (4 - frequently) was observed in the case of $A$. versicolor, while frequency 3 (fairly frequently) was characteristic of such species as A. flavus and A. niger. A. ustus was encountered with frequency 2 (individually), while frequency 1 (sporadically) referred to four species: A. carbonarius, A. clavatus, A. fumigatus and A. terreus. Because Aspergillus versicolor occurs with the highest frequency in buildings, and as a consequence of this, synthesizes toxic and carcinogenic sterigmatocystin (ST), it constitutes the greatest risk to the inhabitants of the infested premises. All species of Aspergillus present on building partitions are able to synthesise mycotoxins, are pathogens and may cause allergies.
\end{abstract}

Keywords: Aspergillus species, mycotoxins, residential housing

\section{INTRODUCTION}

The occurrence of moulds on building partitions is a problem whose severity has been increasing in many countries, not just in Poland. This

\footnotetext{
${ }^{1}$ Corresponding author: University of Zielona Gora, Faculty of Civil Engineering, Architecture and Environmental Engineering, Institute of Environmental Engineering, Department of Applied Ecology, Z. Szafrana st 15, 65-516 Zielona Góra, Poland, e-mail: m.piontek@iis.uz.zgora.pl, tel. +48683282679
} 
negative phenomenon in buildings contributes to the bio-deterioration of building materials and reduces the sanitary quality of the internal air [1-3]. Analyses regarding the internal environment, which have been conducted in the recent years, indicate the two most dangerous species: Stachybotrys chartarum and Aspergillus versicolor [4-7, 3]. These moulds are able to synthesise such mycotoxins dangerous to the health of inhabitants as: macrocyclic trichothecenes, trichodermin and satratoxin G (S. chartarum) or sterigmatocystins (A. versicolor). The above-mentioned compounds can be present in the majority of samples coming from the building materials of damp flats and from samples of settled dust [8].

Regardless of whether the microorganisms grow on brick walls, concrete walls, plasterboard walls, wall paper, wood or silicone joints, they still constitute the source of spores and fragments of mycelium as well as airborne mould from the building materials inside the building, which are all dangerous to the health of its inhabitants [9-11, 7]. New technologies applied in the construction industry are conducive to the development of mould on building partitions. Therefore, it is important to demonstrate the mycological risks, which these microorganisms may pose for the health of the inhabitants, as well as any loss of the utility properties of the materials which the walls are made of [7].

The basis for the evaluation of the risks caused by an infestation with mould in residential housing is mycological analysis. The area of the Lubuskie Province (Poland) has been selected as a sufficiently large and representative research area for many buildings found in Europe in the temperate climate zone. The aim of the research was to determine the frequency of moulds species occurrence on infected building partitions. The species which were most frequently present in residential housing were identified and the conclusion was drawn that thermal-upgrading renovations caused an increase in the number of premises infested with moulds, as well as a negative quality change, since the less toxic moulds which most frequently colonise building partitions were replaced by the Aspergillus species which are capable of synthesizing, among others: $\mathrm{AFB}_{1}$, ST, 5-ST, OTA or PAT.

A factor which always determines the growth of moulds on building partitions is the soil humidity. It is important to know the specific humidity requirements for moulds isolated in flats, with particular consideration given to the Equilibrium Relative Humidity $\mathrm{a}_{\mathrm{w}}-$ water activity. The humidity required for the growth of Aspergillus is presented in table 1. The humidity level also determines the division into the 3 succession groups (primary, secondary and tertiary colonisers). 
Table 1. Required humidity for the growth of selected microorganisms which belong to the genus Aspergillus, in buildings, on finishing materials and interior equipment [12-15]

\begin{tabular}{|l|l|}
\hline Humidity level & Category of microorganisms \\
\hline High $\left(\mathrm{a}_{\mathrm{w}}>0.90 ;\right.$ ERH $\left.>90 \%\right)$ & Tertiary colonisers (hydrophils) \\
& Aspergillus fumigatus \\
\hline Medium $\left(\mathrm{a}_{\mathrm{w}} 0.80-0.90 ;\right.$ ERH 80-90\%) & Secondary colonisers \\
& Aspergillus clavatus \\
& Aspergillus flavus \\
& Aspergillus ochraceus \\
& Aspergillus terreus \\
& Aspergillus versicolor ${ }^{a}$ \\
\hline Low $\left(\mathrm{a}_{\mathrm{w}}<0.80 ; \mathrm{ERH}<80 \%\right)$ & Primary colonisers $(\mathbf{x e r o p h i l s})$ \\
& Aspergillus niger \\
& Aspergillus versicolor ${ }^{b}$ \\
\hline
\end{tabular}

$\mathrm{a}_{\mathrm{w}}$, - water activity; ERH - equilibrium relative humidity; a at $12{ }^{\circ} \mathrm{C} ;{ }^{\mathrm{b}}$ at $25^{\circ} \mathrm{C}$

Moulds which represent the Aspergillus genus can grow on building partitions already at a low humidity level $\left(\mathrm{a}_{\mathrm{w}}<0.80\right)$, which causes them to appear on walls with higher and higher frequency.

\section{MATERIALS AND METHODS}

Mycological analyses were carried out in more than 280 buildings. Samples were collected from the inner surfaces of building partitions with visible mould. The partitions were made of plasterboard, bricks, breeze blocks and concrete slabs, and the finishing materials included: plaster, acrylic paint, wallpaper etc. The samples were collected directly at the site of occurrence and transferred onto Petri dishes, which contained both the natural media such as Malt Extract Agar (MEA), (Merck), Potato Dextrose Agar (PDA), (Merck) and synthetic media such as Czapek - Dox Agar (Merck) and Seawater Nutrient Agar (SNA), (Merck). The analysis was performed in accordance with the methodology established by CBS (Centraalbureau voor Schimmelcultures), [15]. The direct plating method was used. According to this method, small fragments of the material infected with moulds are transferred or spread onto the Petri dishes containing the culture media [16]. The samples were covered with white linen and incubated in a cultivation room at a room temperature between $18^{\circ}$ and $22^{\circ} \mathrm{C}$, maintaining the circadian rhythm of day and night. Pure (axenic) cultures were isolated from mixed starter cultures by their passaging on the media: Czapek-Dox and MEA. The time of plating, cultivation and observation for an isolated single species was 21 days $[17,18]$. The isolated strains were 
subjected to identification tests using keys for taxonomic identifiers: 19-32, 15.

The frequency with which the isolated mould species was present in the tested residential premises was determined. According to Piontek [33], their percentage share was expressed using the five-grade scale (1-5), (table 2).

Table 2. Frequency of occurrence of moulds in residential housing according to Piontek [33]

\begin{tabular}{|c|c|}
\hline Frequency (\%) & Scale \\
\hline $0-5 \%$ & 1 - sporadically \\
\hline$>5-10 \%$ & 2 - individually \\
\hline$>10-15 \%$ & 3 - fairly frequently \\
\hline $15-20 \%$ & 4 - frequently \\
\hline$>20 \%$ & 5 - very frequently \\
\hline
\end{tabular}

\section{RESULTS AND DISCUSSION}

The mycological analyses conducted in the residential housing in the area of the Lubuskie province suggest that there are 83 species of moulds present on building partitions. The following species were observed with the highest frequency: Cladosporium herbarum and Penicillum chrysogenum - frequency 5, (table 3).

Table 3. Frequency of moulds observed on building partitions in the area of the Lubuskie Province [3, supplemented]

\begin{tabular}{|l|l|c|}
\hline \multicolumn{2}{|c|}{ Types and species of moulds } & Frequency in flats * \\
\hline Absidia & corymbifera Sacc. et Trotter & 1 \\
\hline & glauca Hagem & 1 \\
\hline Acremonium & bacillisporum W. Gams & 1 \\
\hline & charticola W. Gams & 1 \\
\hline & murorum W. Gams & 1 \\
\hline & strictum W. Gams & 2 \\
\hline Alternaria & alternata Keissler & 1 \\
\hline & tenuissima Wiltshire & 1 \\
\hline Arthrinium & phaeospermum M.B. Ellis & 1 \\
\hline Aspergillus & carbonarius Thom & 1 \\
\hline & clavatus Desmazieres & 1 \\
\hline & flavus Link & 3 \\
\hline & fumigatus Fressenius & 1 \\
\hline & niger van Tieghem & 1 \\
\hline & ochraceus Wilhelm & 3 \\
\hline & terreus Thom & \\
\hline
\end{tabular}


IN RESIDENTIAL HOUSING AND PUBLIC UTILITY PREMISES

\begin{tabular}{|c|c|c|}
\hline & ustus Thom et Church & 2 \\
\hline & versicolor Tiraboschi & 4 \\
\hline Aureobasidium & pullulans Arnaud & 1 \\
\hline Beauveria & bassiana Vuillemin & 1 \\
\hline Botrytis & cinerea Persoon ex Fries & 1 \\
\hline Botryotrichum & piluliferum Sacc. et Marchal & 1 \\
\hline \multirow[t]{2}{*}{ Chaetomium } & elongatum Czerepanova & 2 \\
\hline & torulosum Bainier & 1 \\
\hline Chromelosporium & $s p$. & 1 \\
\hline \multirow[t]{4}{*}{ Cladosporium } & cladosporioides de Vries & 2 \\
\hline & herbarum Link ex Gray & 5 \\
\hline & macrocarpum Preuss & 3 \\
\hline & sphaerospermum Penzig & 1 \\
\hline Doratomyces & stemonitis Pers. & 1 \\
\hline Epicoccum & nigrum Link & 1 \\
\hline \multirow{8}{*}{ Fusarium } & aquaeductum Lagerheim & 1 \\
\hline & culmorum Saccardo & 1 \\
\hline & equiseti Saccardo & 1 \\
\hline & oxysporum Schlechtendal ex Fries & 1 \\
\hline & sambucinum Fuckel & 1 \\
\hline & solani Saccardo & 1 \\
\hline & sporotrichioides Sherbakoff & 1 \\
\hline & verticillioides Nirenberg & 1 \\
\hline Geotrichum & candidum Link & 1 \\
\hline Gilmaniella & humicola Barron & 1 \\
\hline \multirow[t]{2}{*}{ Humicola } & brevis Gilman et Abbott & 1 \\
\hline & fuscoatra Traaen & 1 \\
\hline Monocillium & indicum S. B. Saksena & 1 \\
\hline Moniliella & acetobutens Stolk \& Dakin & 1 \\
\hline \multirow{7}{*}{ Mucor } & circinelloides van Tieghem & 1 \\
\hline & globosus Fischer & 1 \\
\hline & hiemalis Wehmer & 1 \\
\hline & mисеdo Fresenius & 1 \\
\hline & piriformis Fischer & 1 \\
\hline & plumbeus Bonorden & 1 \\
\hline & racemosus Fresenius & 3 \\
\hline \multirow[t]{3}{*}{ Paecilomyces } & farinosus Brown et Smith & 1 \\
\hline & marquandii Hughes & 1 \\
\hline & variotii Bainier & 1 \\
\hline \multirow[t]{3}{*}{ Penicillium } & aurantiogriseum Dierckx & 1 \\
\hline & brevicompactum Dierckx & 1 \\
\hline & chrysogenum Thom & 5 \\
\hline
\end{tabular}




\begin{tabular}{|l|l|c|}
\hline & expansum Link ex Gray & 1 \\
\hline & funiculosum Thom & 1 \\
\hline & glabrum Westling & 1 \\
\hline & janthinellum Biourge & 1 \\
\hline & lanosum Westling & 3 \\
\hline & thomii Maire & 1 \\
\hline & viridicatum Westling & 1 \\
\hline & vulpinum Seifert et Samson & 1 \\
\hline & waksmanii Zaleski & 1 \\
\hline Phoma & glomerata Corda) Wollenw. & 1 \\
\hline Rhizomucor & pusillus Schipper & 1 \\
\hline Rhizopus & stolonifer Lind. & 2 \\
\hline Scopulariopsis & brevicaulis Bainier & 1 \\
\hline & candida Vuill. & 1 \\
\hline Stachybotrys & chartarum Hughes & 1 \\
\hline Thamnidium & elegans Link & 2 \\
\hline Trichoderma & koningii Oudemans & 1 \\
\hline & viride Persoon ex Gray & 2 \\
\hline Trichothecium & roseum Link ex Gray & 2 \\
\hline Tritirachium & oryzae (Vincens) de Hoog & 1 \\
\hline Ulocladium & botrytis Preuss & 2 \\
\hline & chartarum Simmons & 4 \\
\hline & consortiale Simmons & 1 \\
\hline Verticillium & lecanii Viégas & 2 \\
\hline & luteoalbum Subramanian & 1 \\
\hline
\end{tabular}

*Frequency in flats (table 2); shaded moulds with a frequency higher than 1

Mycological analysis demonstrated a significant qualitative change in the mould species in relation to the studies conducted by Piontek during the preceding years [33,3]. A significantly higher frequency on building partitions was observed in the case of such species as Aspergillus in lieu of such moulds as e.g. Mucor racemosus (the frequency of occurrence on partitions had decreased from 4 to 3 ).

The genus Aspergillus and its teleomorphs currently contain 254 accepted species [34]. Studies have shown that Aspergilli on the walls are represented by 9 species. They constitute $11 \%$ of all the species isolated from the partitions in the Lubuskie province. The highest frequency among them - 4 (frequently) was demonstrated by Aspergillus versicolor. Such species as: A. flavus, A. figer occurred with a frequency of 3 . One species A. ustus was observed individually (frequency 2), while such species' as A. carbonarius, A. clavatus, A. fumigatus, A. ochraceus and A. terreus were present only sporadically. Despite the low frequency of occurrence, the presence of these species on building partitions cannot be assumed to 
remain without any effect on the health of the inhabitants, as they have biochemical abilities to synthesize mycotoxins and cause allergies and mycosis.

All the identified species are widespread in nature, and can also colonise building materials. Each of the 9 species of Aspergillus has the ability to synthesize secondary metabolites and mycotoxins. The mycotoxins synthesized by Aspergilli are listed in table 4.

Table 4. List of mycotoxins and secondary metabolites synthesized by moulds of the genus Aspergillus

\begin{tabular}{|c|c|}
\hline Species & $\begin{array}{l}\text { Formed mycotoxins and secondary metabolites* } \\
\qquad[35,36,15,7]^{*}\end{array}$ \\
\hline $\begin{array}{l}\text { A. carbonarius } \\
\text { Thom }\end{array}$ & ochratoxin A \\
\hline $\begin{array}{l}\text { A. clavatus } \\
\text { Desmazieres }\end{array}$ & $\begin{array}{l}\text { cytochalasin E, patulin, ascladiol, tryptocuivalin, tryptocuivalon, } \\
\text { kojic acid }\end{array}$ \\
\hline A. flavus Link & $\begin{array}{l}\text { aflatoxin } \mathbf{B}_{1}, \mathbf{B}_{2}, \mathbf{G}_{1}, \mathbf{G}_{2} \text {, cyclopiasonic acid, 3-nitropropionic } \\
\text { acid, sterigmatocystin, aflatrem, aspertoxin, flavicidin, } \\
\text { aspergillic acid, kojic acid, } \beta \text {-nitropionic acid, o-methyl } \\
\text { sterigmatocystin }\end{array}$ \\
\hline $\begin{array}{l}\text { A. fumigatus } \\
\text { Fressenius }\end{array}$ & $\begin{array}{l}\text { fumitremorgin } \mathbf{A}, \mathbf{B}, \mathbf{C} \text {, gliotoxin, verruculogen, fumigaclavin } \\
\text { A, B, C, fumitoxins (fumigacin, fumagillin), tryptocuivalins, kojic } \\
\text { acid }\end{array}$ \\
\hline $\begin{array}{l}\text { A. niger van } \\
\text { Tieghem }\end{array}$ & $\begin{array}{l}\text { malformins A, B, C, naphtho-y-pyrones, ochratoxin A, } \\
\text { nigragillin }\end{array}$ \\
\hline $\begin{array}{l}\text { A. ochraceus } \\
\text { Wilhelm }\end{array}$ & $\begin{array}{l}\text { ochratoxin A, penicillic acid, xahthomegnin, viomellein, } \\
\text { vioxantin }\end{array}$ \\
\hline A. terreus Thom & $\begin{array}{l}\text { citreoviridin, citrinin, gliotoxin, patulin, kojic acid, usitin acid, } \\
\text { terreic acid }\end{array}$ \\
\hline $\begin{array}{l}\text { A. ustus Thom } \\
\text { et Church }\end{array}$ & austamide, austdiol, austocystins $A$ and $B$ \\
\hline $\begin{array}{l}\text { A. versicolor } \\
\text { Tiraboschi }\end{array}$ & $\begin{array}{l}\text { cyclopiasonic acid, sterigmatocystin, 5-methoxy- } \\
\text { sterigmatocystin, dihydroxy-sterigmatocystin, nidulotoxin, } \\
\text { averufin, versiconol, versicolorin A, B, C }\end{array}$ \\
\hline
\end{tabular}

* important toxic metabolites are listed in bold

The International Agency for Research of Cancer (IARC) published the list of carcinogenic substances, using the following grading scale: 1, 2A, 2B, 3, 4 . The greatest danger is caused by such toxic and carcinogenic mycotoxins as aflatoxin $\mathrm{B}_{1}$ synthesized by A. flavus (1 - an epidemiologically confirmed relationship between the exposure and the incidence of a disease), ochratoxin A (A. carbonarius, A. niger, A. ochraceus) and sterigmatocystin (A. flavus, A. veriscolor), which were qualified into category 2 B (lesser probability of carcinogenic effect), [37]. 
Table 5 presents the data regarding the mortality of selected test organisms after subjecting them to acute toxicity tests for $\mathrm{AFB}_{1}$, OTA and ST.

Table 5. Comparison of toxicity of aflatoxin $\mathrm{B}_{1}$, ochratoxin and sterigmatocystin for test animals [35, 38, 7, 18, 3]

\begin{tabular}{|c|c|c|c|c|}
\hline Test organism & Mortality rate & $\mathbf{A F B}_{1}$ & OTA & ST \\
\hline Ducklings & LD $50\left(\mathrm{mg} \mathrm{kg}^{-1}\right)$ & 0.012 & 3.0 & 1.0 \\
\hline Rats & LD $50\left(\mathrm{mg} \mathrm{kg}^{-1}\right)$ & $5.5-17.9$ & $3.9-22$ & $65-166$ \\
\hline Mice & LD $50\left(\mathrm{mg} \mathrm{kg}^{-1}\right)$ & $3-9$ & 500 & 800 \\
\hline Chicken embryos & $\mathrm{LD} 50\left(\mathrm{mg} \mathrm{kg}^{-1}\right)$ & $\begin{array}{c}0.05 \\
\mu \mathrm{g} / \mathrm{embryo}\end{array}$ & $\begin{array}{c}0.4-2.0 \\
\mu \mathrm{g} / \text { embryo }\end{array}$ & $\begin{array}{c}15 \\
\mu \mathrm{g} / \text { embryo }\end{array}$ \\
\hline Chickens & $\mathrm{LD} 50\left(\mathrm{mg} \mathrm{kg}^{-1}\right)$ & 2 & $3-4$ & $10-14$ \\
\hline $\begin{array}{c}\text { Shrimp larvae } \\
\text { (Artemia salina) }\end{array}$ & LC $50\left(\mathrm{mg} \mathrm{dm}^{-3}\right)$ & $1.3-39.0$ & $10.1-26.4$ & $0.54-5.95$ \\
\hline $\begin{array}{c}\text { Planarians } \\
\text { (Dugesia tigrina) }\end{array}$ & LC $50\left(\mathrm{mg} \mathrm{dm}^{-3}\right)$ & Not tested & Not tested & $8.2-603$ \\
\hline
\end{tabular}

The combined data regarding the test animals indicates that the moulds of the genus Aspergillus synthesize toxins which are dangerous to the health of the inhabitants. The obtained results show that sterigmatocystin is about 10 times less toxic than aflatoxin $B_{1}$ for rats and 100 times less toxic for mice and chicken embryos, but it is a hepatocarcinogenic substance and tests conducted on animals prove that $A$. versicolor consequently synthesizes ST on building materials. Toxicological studies conducted at the laboratory of the Institute of Environmental Engineering of the Zielona Góra University, using planarians, demonstrated the varied toxicity of strains of $A$. versicolor coming from buildings. The LC 50 values ranged between 8.2 - $603 \mathrm{mg} \mathrm{dm}^{-3}$, which means that strains ranging between lowproductive (non-poisonous) and very strongly poisonous may occur in buildings $[18,3]$. All the toxins synthesized by Aspergilli create a potential risk in buildings, therefore, their presence on building partitions must not be tolerated.

Moulds are pathogens. In 1996, under the auspices of the European Confederation of Medical Mycology, a list which sets out the BSL classification was drawn up for the respective species of moulds (BSL 1 - 3), [29]. On this basis it is possible to determine the potential risk to people who live in infested rooms. Table 6 contains the BSL classification for isolated species of the genus Aspergillus. 
Table 6. Biosafety levels of selected moulds potentially pathogenic for man and animals (BSL), [29]

\begin{tabular}{|l|l|c|}
\hline \multicolumn{2}{|c|}{$\begin{array}{c}\text { Species of moulds of the genus } \\
\text { Aspergillus }\end{array}$} & $\begin{array}{c}\text { *BSL, indicative risk assessment to } \\
\text { people and animals }\end{array}$ \\
\hline Aspergillus & carbonarius Thom & - \\
\hline & clavatus Desmazieres & 2 \\
\hline & flavus Link & 2 \\
\hline & fumigatus Fressenius & 1 \\
\hline & niger van Tieghem & 1 \\
\hline & ochraceus Wilhelm & 2 \\
\hline & terreus Thom & 1 \\
\hline & ustus Thom et Church & 1 \\
\hline & versicolor Tiraboschi & \\
\hline
\end{tabular}

*BSL1-infections are superficial, non-invasive or benign,

BSL2 - in patients with severe immunological disorders, moulds can cause deep opportunistic infections,

BSL3 - pathogens potentially capable of inducing severe deep fungal infections in apparently healthy people.

The BSL2 category comprises as many as 3 species: A. flavus, A. fumigatus and $A$. terreus. These are the species which can cause aspergillosis. The other species from the genus Aspergillus are categorised as BSL 1 - they can cause coincidental, superficial, non-invasive and benign infections. The most dangerous pathogens (BSL3), which are potentially able to cause severe and deep fungal infections in persons with overall good health did not occur in the analysed flats in the Lubuskie province.

\section{CONCLUSIONS}

The mycological tests in buildings in the temperate climate zone demonstrated the qualitative change in the mould species that infest the building partitions. 9 species of moulds that represent the genus Aspergillus (Photo 1- 9 [27]) were isolated from and identified on infested building partitions. All the species are able to synthesize mycotoxins, are pathogens and can cause allergies. It was concluded that the frequency of the moulds of the genus Aspergillus, which can constitute the potential risk to the health of the inhabitants of the infested premises had increased, therefore mycological analyses in buildings are important and must be continued. 


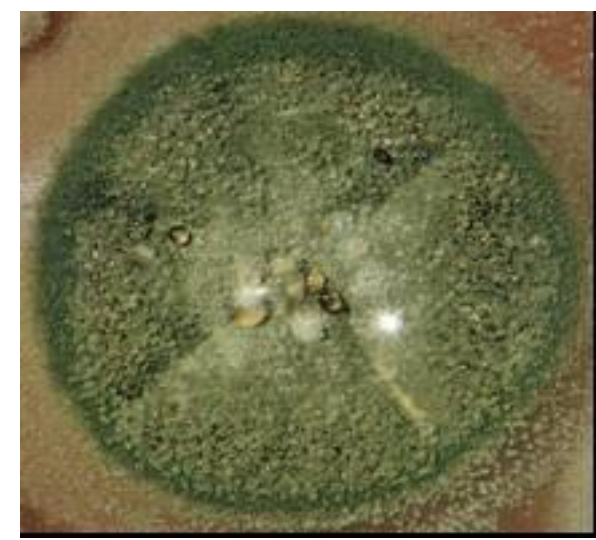

Photo 1. Aspergillus versicolor (Vuillemin) Tiraboschi on Czapek Dox medium

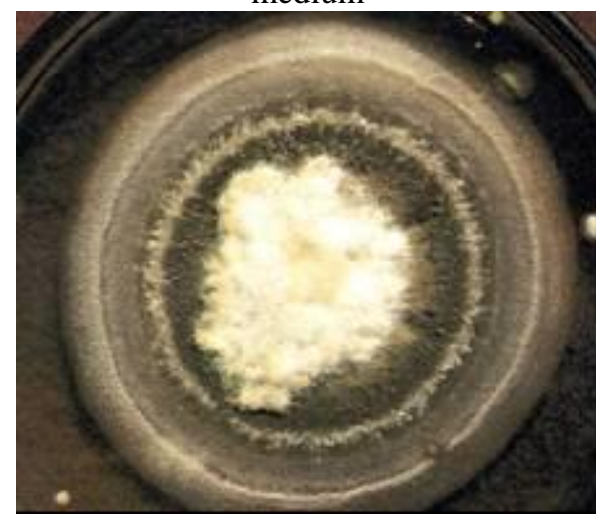

Photo 3. Aspergillus ustus (Bainier) Thom et Church

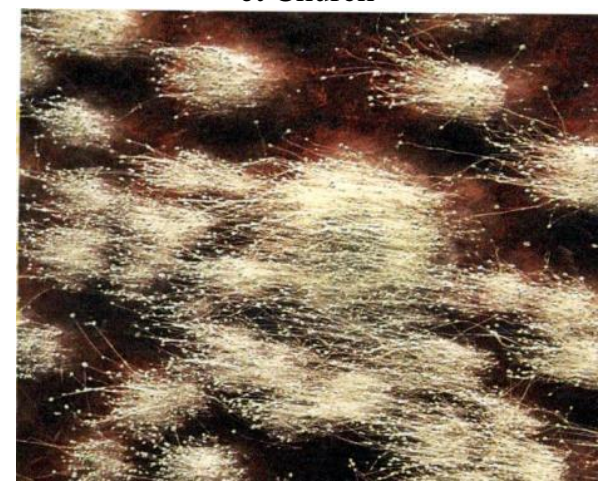

Photo 5. Aspergillus clavatus Desmazieres

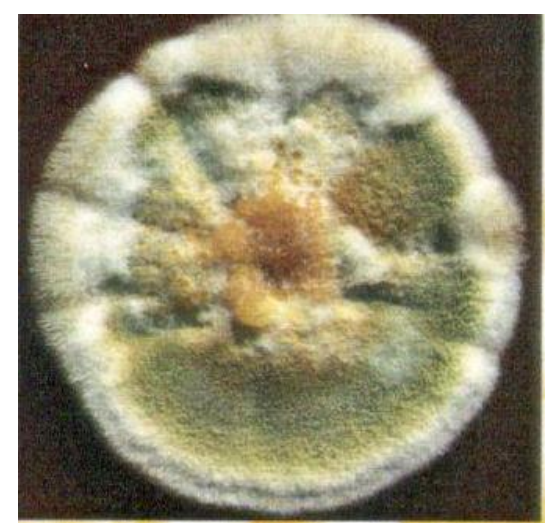

Photo 2. Aspergillus versicolor (Vuillemin) Tiraboschi on MEA

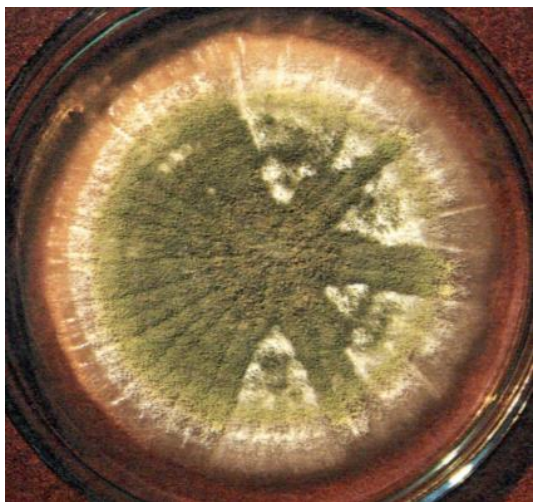

Photo 4. Aspergillus flavus Link ex F. Gray

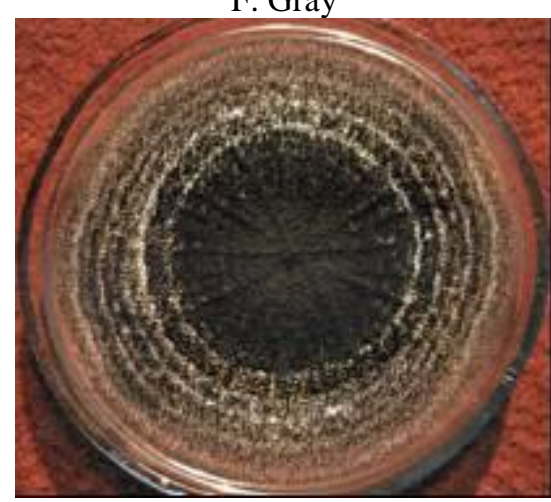

Photo 6. Aspergillus niger van Tieghem 


\section{REFERENCES}

1. Piontek M., Jasiewicz M., Bednar K., Mould biodeterioration caused by technological defects in dwelling buildings. Ochrona Przed Korozja 2010 (1): 8-13.

2. Piontek M., Jasiewicz M., Łuszczyńska K. Thermal modernization and biodeterioration of prefabricated elements of buildings - a case study - W: Management of indoor air quality. Ed. M. R. Dudzińska. London: Taylor \& Francis Group, 2011: 109-122.

3. Piontek M., Łuszczyńska K., Lechów H. Occurrence of the toxin-producing Aspergillus versicolor Tiraboschi in residential buildings. International Journal of Environmental Research and Public Health, 2016, Vol. 13 (9): $1-12$.

4. Dales R.E., Zwanenburg H., Burnett R., Franklin C.A. Respiratory health effects of home dampness and molds among Canadian children. Am.J.Epidemiology. 1991, 134: 196-206.

5. Hendry K.M., Cole E.C. A review of mycotoxins in indoor air. J.Toxicol. Environ. Health, 1993, 38: 138-198.

6. Johanning E., Biagini R., Hull D., Morey P., Jarvis B., Landsbergis P. Health and immunology study following exposure to toxigenic fungi (Stachybotrys chartarum) in water-damaged office environment. Int. Arch. Occup. Environ. Heath. 1996, 68: 207-218.

7. Piontek M. Moulds and Estimation of Mycotoxic Threat in Dwelling Buildings, Zielona Góra, Wydawnictwo Uniwersytetu Zielonogórskiego, Poland, 174 pp., 2004.

8. Bloom E., Bal K., Nyman E., Must A., Larsson L. Mass spectrometry-based strategy for direct detection and quantification of some mycotoxins produced by Stachybotrys and Aspergillus spp. in indoor environments. Applied and Environmental Microbiology, 2007, 73(13): 4211 - 4217

9. Hunter, C.A., Grant, C., Flannigan, B., Bravery, A.F. Mould in buildings: the air spora of domestic dwellings. International Biodeterioration 1988, 24 $81-101$.

10. Warnock, D., Campbell, C.K. Centenary reviev: medical mycology. Mycol. Res. 1996, 100: 1153 - 1162.

11. Flannigan B. Microbial aerosols in buildings: origin, health implications and controls. In: Proceedings of the II Conference on microbial biodegradation and biodeterioration of technical materials, Łódź, Poland, 2001, 11 - 27.

12. Grant C., Hunter, C.A., Flannigan, B., Bravery, A.F. Water activity requirements of moulds isolated from domestic dwellings. International Biodeterioration 1989, 25: 259 - 284. 
13. Gravesen S., Frisvad J.C, Samson R.A., Microfungi. Munksgaard, Copenhagen, 1994.

14. ISIAQ. TFI - 1119. Control of moisture problems affecting biological indoor air quality. Espoo, International Society of Indoor Air Quality and Climate (ISIAQ guideline, task force 1-1996; http://www.isiaq.org.publication.asp, accessed 12 May 2009), 1996.

15. Samson R.A, Hoekstra E.S., Frisvad J.C, Introduction to food and airborne fungi. Seventh Ed. Utrecht. Centralbureau voor Schimmercultures (CBS) The Netherlands, 2004.

16. Hoekstra E.S, Samson R.A. Summerbell R.C. Methods for the detection and isolation of fungi in the indoor environments. W: R.A. Samson, E.S. Hoekstra, J.C. Frisvad, (red.) Introduction to food and airborne fungi. Seventh Ed. Utrecht. Centralbureau voor Schimmercultures (CBS) The Netherlands, 2004.

17. Piontek M. Strains of Aspergillus versicolor Tiraboschi synthesizing sterigmatocistin and the differentiation of mycotoxic risk dependent on their productivity in housing buildings. Mycotoxin Research 2007, Vol.23 (1): 34-38.

18. Piontek M. Use of planarian Dugesia tigrina Girard bioassay for assessing the toxicity of sterigmatocistin produced by Aspergillus versicolor Tiraboschi. Environment Protection Engineering, 2010, Vol. 36 (1): 65-71.

19. Cooke W.B. A laboratory guide to fungi in polluted waters, sewage and sewage treatment systems. Ohio, U. S. Dept. Health. Education and Welfare 132 pp., 1963.

20. Barnett H.L. Illustrated Genera of Imperfect Fungi. Burgess Publ. Co., Minneapolis, 1965.

21. Raper, K.B., Fennel D.I. The Genus Aspergillus. Baltimore. The Williams and Wilkins Company 686 pp. 1965.

22. Litvinov M.A. Opredelitel' Mikroskopicheskikh Pochvennykh Gribov, Leningrad, 475 pp., 1967.

23. Domsch, K.H., Gams, W., Anderson Traute-Heidi. Compendium of soil fungi. I, II. London, N.Y., Toronto, Sydney, San Francisco, Acad. Press. 859+405 pp., 1980.

24. Fassatiova O. Moulds in technical microbiology. WNT, Warszawa, 255 pp., 1983.

25. Klich M. A., Pitt J.I. A laboratory Guide to common Aspergillus species and their teleomorphs. North Ryde, NSW: CSIRO Division of Food Processing, Australia 116 pp., 1988.

26. Kwaśna, H., Chełkowski, J., Zajkowski, P. Mycota, Tom XXII, Fusarium. PAN, Inst. Bot., Warszawa-Kraków,1991. 
27. Piontek M. Moulds Atlas. Zielona Góra, Wydawnictwo Politechniki Zielonogórskiej 113 pp., 1999.

28. Pitt J.I., Hocking A.D. Fungi and food spoilage. Academic Press $2^{\text {nd }}$ ed. 593 pp., 1997.

29. Hoog de G.S., Guarro J. Atlas of clinical fungi, second ed. Centralbureau voor Schimmelcultures (CBS), Utrecht, 2000.

30. Pitt J.I. A laboratory guide to common Penicillium species. Third Ed. North Ryde, Australia, Commonw. Scient. Industry Res. Organisation 197 pp., 2000.

31. Klich M.A. Identification of common Aspergillus species. Utrecht: Centraalbureau voor Schimmelcultures, 116 pp. , 2002.

32. Samson. R.A., Houbraken J., Thrane U., Frisvad J.C. \& Andersen B. Food and Indoor Fungi, CBS KNAW Biodiversity Center; CBS Manual Series 2, Utrecht, 390 pp., 2010.

33. Piontek, M. Moulds occurring in buildings of the Lubuskie province, Poland. In: Proceedings of the II Conference on microbial biodegradation and biodeterioration of technical materiale, Łódź. Poland, 2001: 86 - 94.

34. Pitt J.I., Samson, R.A., Frisvad, J.C. List of accepted species and their synonyms in the family Trichocomaceae. In: Samson, R.A., Pitt, J.I. [Eds] Integration of modern taxonomic methods from Penicillium and Aspergillus classification. Amsterdam. The Netherlands. Harwood Academic Publishers 2000: 9 - 49.

35. Cole R.J., Cox R.H. Handbook of toxic fungal metabolites. New York, Acad. Press, 937 ss., 1981.

36. Nielsen F.K. Mycotoxin production by indoor molds. Fungal Genetics and Biology 2003, 39: 103-117.

37. IARC. List of classifications, Volumes 1-118. In: International Agency for Research of Cancer. Monographs on the evaluation of the carcinogenic risk of chemicals to humans. Lyon, IARC online 2017.

38. Chełkowski, J. Mycotoxins, mycotoxin-producing fungi and mycotoxicosis. Warszawa. Wydawnictwo SGGW-AR 95 pp., 1985.

\section{ASPERGILLI NA PRZEGRODACH BUDOWLANYCH ZAINFEKOWANYCH GRZYBAMI PLEŚNIOWYMI POMIESZCZEŃ MIESZKALNYCH I UŻYTECZNOŚCI PUBLICZNEJ}

Streszczenie

Grzyby pleśniowe z rodzaju Aspergillus stanowią poważne zagrożenie dla zdrowia mieszkańców zainfekowanych pomieszczeń. Badania mikologiczne przeprowadzone 
w porażonych grzybami obiektach na terenie województwa lubuskiego (Polska) wykazały występowanie 9 gatunków grzybów z rodzaju Aspergillus: A. carbonarius A. clavatus, A. flavus, A. fumigatus, A. niger, A. ochraceus, A. terreus, A ustus, A. versicolor. $\mathrm{Z}$ największą frekwencją (4 - często) wystąpił A. versicolor, natomiast z frekwencją 3 (dość często) wystąpiły takie gatunki jak A. flavus oraz A. niger. A. ustus wystąpił $\mathrm{z}$ frekwencją 2 (pojedynczo), natomiast $\mathrm{z}$ frekwencją 1 (sporadycznie) wystąpiły cztery gatunki: A. carbonarius, A. clavatus, A. fumigatus i A. terreus. Stwierdzono, że gatunek Aspergillus versicolor przez to, że występuje z największą frekwencją w budownictwie oraz konsekwentnie syntetyzuje toksyczną i kancerogenną sterygmatocystynę ST stanowi największe niebezpieczeństwo dla mieszkańców zainfekowanych pomieszczeń. Wszystkie gatunki z rodzaju Aspergillus posiadają zdolność do syntezy mikotoksyn, są patogenami oraz mogą powodować alergie.

Słowa kluczowe: Aspergillus, mikotoksyny, budownictwo

Editor received the manuscript: 01.12.2017 